\title{
Mass and Individual: \\ Organized Conflict Against Spontaneity
}

\author{
Boris I. Khasan* and Tatiana I. Yustus \\ Siberian Federal University \\ 79 Svobodny, Krasnoyarsk, 660041, Russia
}

Received 18.02.2017, received in revised form 05.12.2017, accepted 14.12.2017

The authors' goal is to present to professional community the way to perceive conflict of individual and mass education not only as a destructive phenomenon, but also as a useful one that allows dealing with contradiction of mass-oriented educational institutions and attitudes, aspirations, intentions of an individual in the educational reality in a productive way.

Keywords: individuality, mass education, productive conflict.

The study was financially supported by the Russian Foundation for Humanities (RFH) within the framework of the research project "Methodological approaches to the monitoring of migration flows for the formation of a management quality system aimed at the population of Siberia and the development of differentiated territorial policy in the country”. Also this project № 15-12-24008 was supported by Krasnoyarsk Regional Fund for Supporting Scientific Research and Technical Research Activities.

DOI: $10.17516 / 1997-1370-0181$.

Research area: psychology.

The whole world cannot create this - the simplest desire (which is freedom, by the way, a free phenomenon).

M.K. Mamardashvili. The Diary Notes.

The authors of the article occupy interesting positions, the two extreme points on the so called educational line: one of the authors is the head of the pre-school educational institution; another is in charge of a particular university master's program. Due to individual experience and specific ideas about the phenomenology of educational relations, it is assumed that our phenomenological representation is no less important than formalized statistical data.
Preschool stage is the place and period when the family first meets the system as an organization. It is the time when a unique individual (the only one in the world) faces a new reality and joins a mass called "Kindergarten". In the current situation parents, as a rule, are happy that they are lucky to use the guaranteed public good. Here on the one hand, for the first time the family and the child learn to equalize their expectations about the system, on the other

(C) Siberian Federal University. All rights reserved

* Corresponding author E-mail address: khbi@ippd.ru 
hand, they get the first experience of fighting for a specific, special attitude to an individual person.

At the other end of the educational institutionalization spectrum, i.e. at the end of the master's program period, there are real students, who came out of the blue. As they are expected to be independent, competent, ready for individual action, almost professionals who need to take a small step in just two years to become real "masters".

What kind of miracle happens on the way and what should occur and be done to make what started as a mass activity end as an individual one? The authors have been looking into this matter for long.

It is clear that the problem of the ratio of the individual and the mass is not new. Ortega y Gasset wrote: "I will begin with what looks extremely paradoxical, but in reality it is simpler: when for a common man the world and life have flung open, his soul has closed tightly for them. And I affirm that this blockage of mediocre souls has given rise to the outrage of the masses, which is becoming a serious problem for humanity".

Naturally, many people think the other way round. This is de rigueur and confirms our idea. Be my view of this complex subject entirely wrong, it is true that many of the opponents have not pondered over it even for five minutes. Can they think like me? But the immutable right to have one's own opinion without any preliminary effort to develop it is just indicative of that absurd state of a person that I call "mass outrage". This is Hermeticism, a blockage of the soul. In this case, Hermetic consciousness. Man has acquired a range of concepts. He/she considers them sufficient and considers him-/herself spiritually perfect. Not feeling anything beyond, this person finally becomes isolated in this range of concepts. This is the mechanism of blockage (Ortega y Gasset, 2001). Here "man" is literally discussed as a mass one, and only in this aspect there appears rebel and opposition to everything that is not mass.

The philosophical tradition of juxtaposing the individual and the mass, which is often understood as social or collective, is refreshed in the J. Habermas's comments: “... On the path chosen by metaphysical thought, the threatened individual reveals oneself (if this happens) ironically as non-identical, as marginal, remaining beyond the reasoning process whenever we try to comprehend the individual at their very core" (Habermas, 1991: 198). Let us pay attention to the word "threatened"! It seems that it is the only way the individual becomes visible. At the end of the $20^{\text {th }}$ century Gilles Lipovetsky asserted optimistically that "the great epoch of revolutionary individualism ends. Once a factor in social warfare, at the present time individualism helps to put a halt on the ideology of the class struggle. In the advanced western countries, the revolutionary era has remained in the past; the class struggle has been established in the form of social institutions (henceforth it does not violate the consistent course of events); the revolutionary parties have completely disappeared; the negotiation process is replacing the brutal clashes. The second individualistic "revolution", accompanying the process of personalization, has led to a mass disillusionment in respublica and, in particular, in ideology: an excess of political enthusiasm was substituted with indifference to systems based on philosophizing (italics added). Rigid and disciplinary order has become incompatible with destabilization and unconcerned humanization. The process of appeasement has involved the entire society, so the civilization of social conflict is currently developing into a civilization of interpersonal relationships" (Lipovetsky, 2001: 311).

Somewhat simplifying, the general tendency in all texts, regardless of the time of their 
writing, is that, on the one hand, massivization is growing, but at the same time, more and more emphasis is placed on the person, and the latter has to demonstrate the individual more and more. Why does this topic become relevant right now? For example, Krasnoyarsk now hosts the third conference of the "Development Practices" with this topic as a main one.

First, information technologies are spreading and cover practically all spheres of life, they are constantly developing, and due to this some absolutely new collective phenomena appear, but in contrast to this there is an increase in isolation and loneliness. This is the first gap.

The second gap is that the tendency towards standardization is apparent and it is reinforced, though in the current postmodern ideology this is perceived and interpreted as an expansion into the uniqueness and originality of individual life, which gives a rise to protest forms.

In education, we as if are trying to develop standards, we urge and demand to look to them, meanwhile dreaming about and striving for individuality.

Phenomenally these contradictory and often confusing (unique versus mass and/or individual versus collective) aspirations and trends look more like disordered clashes of certain actions that implement the corresponding programs and form such spontaneous outbursts of activity. And it looks like an irresolvable task or as a hindrance.

Therefore, the first statement sounds like this: the authors believe that it is not yet possible to formalize these contradictions in a normal conflict, that is, THERE IS NO REAL CONFLICT BETWEEN THE INDIVIDUAL AND MASS EDUCATION. Or it is extremely rare and occasional. This is the trouble.

Most often, the term "conflicts" means spontaneous collisions or excesses, which are experienced quite intensely by immediate participants and can provoke temporary solidarity of participants who display concern for a specific story or even affect institutions for a while. Here are some examples...

A father brings a three-year-old child to the kindergarten and asks the nursery teacher absolutely sincerely: "My daughter is recommended not to go for a walk today, so please stay with her inside while the others are out". The teacher also has something to ask: "Who will accompany the remaining 22 children for a walk?"

In primary school, when the parents are dissatisfied with the teacher they ask school administration like: "How much do we have to pay to choose the teacher ourselves?" (The question implies: Can we claim for the individual attitude in a school that is targeted on masses?)

Now let us look at the problem from the standpoint of the educational organization. The kindergarten head may tell the parents that in the situation with day nurseries, when there is only 1 teacher with 1 assistant for 29 children (as specified by the budget), they cannot give what the children really need (a good educational result). They know how to manage the achievement of this result and how to ensure the conditions that are required for this age. But this requires having a third adult in the group, and therefore, extrabudgetary funding. Parents are invited to join forces. In fact, it means they should try to fund the work of the third adult. Asked separately, almost everyone says that this is a great idea, but when they gather together, the decision is negative. What does this mean, what is the point of tension? The parents argue: "We came to a state institution and this means that everything that we need should be here as guaranteed by the government. The system is obliged to guarantee satisfying all the needs". And as for the needs, it turns out, they are also indicated by the system itself! In this case they are embodied in an institution of a specific sphere, while the system 
does not need any individuality, though the parents need the latter. This is a strange situation for the parents.

Especially it is indispensable to comment on inclusive education, because it stands apart, and as regards it, we see as if another situation: in case of limited health opportunities they say: "A person has the right to a special, individual attitude". The system agrees with this point and even seems to be tailored specifically to it, so this looks like individualization, but in fact it is not. Unfortunately, so far all that we have been trying to do, design and settle by legal acts, leads to the assumption (presupposition and belief) that since there is a valid reason, the mass must suffer for the sake for someone's special needs. That is not an attempt to resolve the conflict, but a way to somehow react to various experiences and maintain the status quo so that it will not generate suddenly some kind of an incident or, God forbid, social tension.

Other examples are when the system itself tries to pretend that it is individualized. Then we will get paradoxes as the following one: "By the end of the $9^{\text {th }}$ grade everyone should have an individual project...", "In the $10^{\text {th }}$ grade the mass of students must have an individual curriculum...". Such is the mass individualization. The situation with the so-called individual plans is also relevant for the university, and, unfortunately, it looks no less imitative than at school.

School and university experience has many more examples, and the authors state that all these subjects are difficult to regulate, precisely because the contradictions that are manifested in them do not form normal conflicts which can be resolved in a civilized way.

Obviously, the contradiction between mass and individual educational ways (namely theoretically and institutionally different organizations) is centred along different subjects (people concerned):
- the government is interested in the mass education, as through this institution it can regulate the division of labour and its relations with society, ensuring the reproduction of workforce, the balance of social relations, economic security, etc.

- the individual education (that is, focused on the individual image) is of interest to the family and the personality; it is realized in moments of self-determination, which are really unique, in spite of all the attempts of the relevant institutions.

This aggravates the question: what should be done to create NORMAL CONFLICTS?

There are some contradictions in the analysis of those described above conflict phenomena:

- A person wants to be like everyone else and wants to be special.

- The individual wants to be in the system and use its resources and at the same time pursue their own interests, different from those to which the system is oriented.

- The education system is designed to solve the problems of the masses, but also provokes individual movement.

A comment is needed here. The way to treat education as the mass one surmises that we face an unstructured array whose unstructuredness may be overcome by the very education. To see oneself as overcoming and having overcome this unstructuredness is possible only in the opposition to the structure, to its configuration, hierarchy and dynamics, i.e. organization of the masses. Being neglected, this process inevitably leads to individualization. But the situation itself, if viewed as reproduced all the time, exploits this mass and individual relation, in which neither side can be a winner.

Educational process takes place, occurs when structures (forms) appear, and it does not matter whether they are individual or collective, since they are already separated from the masses. 
And we want them to be separate, but the mass origin is the condition for their appearance and the successive separation.

Hence follows the second thesis. WITHOUT MASS EDUCATION INDIVIDUALITY IS NOT POSSIBLE.

What does this thesis give? It is important that while the conflict arises and the involved parties are detected, there is no clash of the mass and the individual (for example, acting through their representatives). There are confronting actions based on the reference to the mass and/ or individualized educational practices. That implies that without and outside the mass origin the individuality does not appear. But maybe it is not necessary at all?

In our own development the answer to this question has become the main one while we were writing the article. Being conflictologists we are sure that the conflict is the developmental mechanism. Therefore, it is obligatory to trace what will not happen if this contradiction does not result in a conflict? It is possible to suppose that if it is not formalized, there is no the very need for the improvement of the educational system and development practices, so it is essential to answer how to make the contradiction lead to a conflict. If we aspire to manage this process, that is, we want to be the ones who manage the education development process, and this is for some reason necessary, we therefore need to make the contradiction a conflict.

To find the answer, let us resort to the technique of constructing conflicts. First, it is required to determine what kind of contradiction demands creating a conflict, then who exactly participates in this conflict, and what actions may lead to its productive resolution.

The contradiction may be stated as follows: "The system is projected for the mass purposes, while a man (individual) deals with a man (individual)".

\section{THE CONSTRUCTIVE CONFLICT} ALLOWS MAINTAINING THIS CONTRADICTION. But under what conditions?

As long as an individual commits an action, his/her own, distinguishing him/her from the masses, and encroaches on the system's resources to satisfy his/her interests, there are grounds for a conflict.

In modern educational reality, despite all the assurances and appeals, individuality is treated as something that prevents "cultivation" and resists it (in genesis), and then it is especially contrasted to "cultivation" as the achieved status, i.e. every time individuality acts as a conflicting party.

The event of the contradiction between the mass and the individual (singular), individuality and collectivity is important, first of all, due to the fact that its actualization forms a conflictual force. More accurately, there had been a conflictual force until we realized that this was a construction that should be organized. It was implicitly grasped and discussed as some orderliness in cultural institutions, for example, in specific age transitions, or in cultural institutions of professionalization and qualification. So every time simultaneously and conjugally this conflict marked the situation of separation from "everybody", whose resource is already exhausted, and of breakthrough to everybody whose resources are to be used. Undoubtedly, this "transition" has a communicative nature and communicative negotiating orderliness.

Such a collision of the aspiring person's actions and both involving and resisting community demands the understanding and realization of an individual responsibility. Responsibility is therefore understood as imprinted and as personalized, i.e. internal, internalized.

For today's (present) segmental pedagogical reality individuality is as if something that must 
be overcome, as a hindrance, not as something that should be cultivated.

In keeping with the constructive thought the authors propose to understand under conflict the clash of actions that contradict each other in such a manner that they would no longer co-exist if they do not change.

Thus, there comes the first task for creating conflict. Who should it involve? Who is the one who conflicts? On the one hand, we have a subject who claims to self-develop (in the Fig. 1 he is on the right). And who should be on the left? This cannot be somebody ensuring the life support system, nor this can be one who only regulates the processes. Their activity objects do not coincide with the object of the first participant. On the left, there can only be the one who claims to develop this system, aspires to it and has the authority to do so.

In general, for a collision to be productive, the parties are efficient when they have interdependent interests and when they own resources. That is, they have something to manage.

In other words, no supervisor of master's or kindergarten programs must keep this contradiction in the resolved state, when there is no interest in, no task of, no orientation on developing the education system or organization.

What interests make this happen? We have already relied on our own experience. And we have wondered for the sake of what we have got involved in this matter.

It is worth starting from the side where the sudden actors (subjects) of development come forward and want something. It is clear that there is a certain image that one wants to achieve, a certain kind of education. The actor knows about it and apprehends it, since the actor solves certain tasks of developing him-/herself. In addition, we cannot exclude self-realization and well-being as his/her interests. The same interest is expressed by the system's representative. He/she is also, of course, interested in self-realization and wellbeing, but apart from that he/she clearly wants something more. There is an orientation towards a special educational result, which one would like to receive, to get something else under the existing conditions. The critical point is his/her interests: he/she wants to create another educational action or have the opportunity to do so. Do anything other than what is functionally prescribed.

So, we already know who conflicts, and why they need it. Then we should ask the following question preceding creating conflicts: what subject of interaction is adequate to the contradiction? It is very difficult to give an answer in one word, but we tried. So the answer is the content and dynamic flexibility of the system. What do these words define? This clash is valuable for the parties and so it is necessary, but

\section{A mere fuctionary}

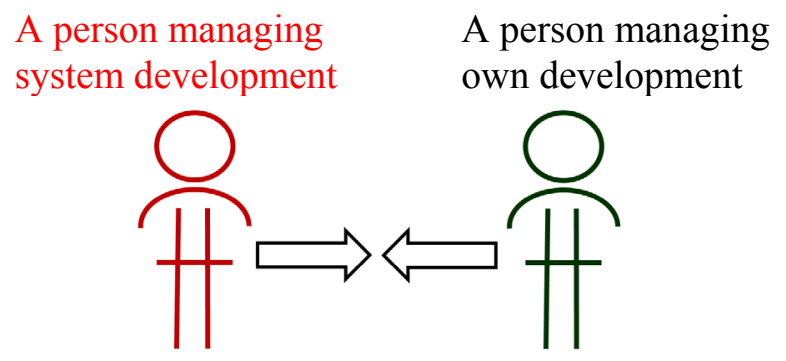

Fig. 1. Parties in a good conflict 


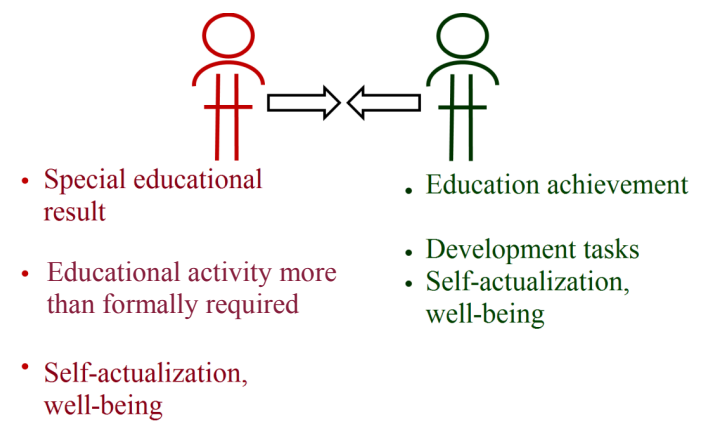

Fig. 2. Interests of the parties

this questions both the content and the procedural predetermined outcome of the system. We hope that if the conflict remains productive as a result of this clash the system will become more flexible, and therefore there will be more adequate ways to solve pressing problems. So both sides need this conflict and this is a good reason for interaction.

Then there is the fourth question concerning the logic of conflict creation: what form should this take, which model of interaction should be used? The answer will not be surprising, here negotiation is needed. What is negotiation? Negotiation is a process of joint decision-making, in which each side has the right of veto. This is what distinguishes the negotiations from everything else, and this is a very rare situation in education, when each of the parties really has the right to veto, when the decision is really made and regulated by both participants. What can be a topic of negotiation or good negotiating points? There are several options. First, the results of education can be the subject of agreement. It turns out that they are not always given, we can and should coordinate them. The second point to coordinate is dynamics of the process and how it will be arranged. This is more difficult, and often looks like an absolutely impossible question for making consistent. But in reality it turns out to be quite possible, when both sides can influence the process dynamics. Use of resources is the third option. In fact, it is often a starting point, but if we want to conduct successful negotiations, we return to the interests and turn to the results, and then we should agree on the indicators which let us know that the results have really been achieved.

Perhaps, it is worth giving some examples. The example from the pre-school education experience is very simple, so it does not seem that conflicts are predestined only for the "advanced" negotiators, in fact negotiation occurs in solving quite simple tasks.

Imagine a kindergarten, a group of four year old children. Their parents expressed interest in strengthening the sports activities. They wanted more physical development for their children than the general kindergarten program specifies. In response, parents were asked to make the group a special one, as we call it in Russian, with a sporting bias. The administration understood that we had specialists interested in such work and ready for it. What happened next? Actually, together with the parents, we discussed what the "bias" means in practice and what results we were waiting for. There, at the pre-school level, there were expressed ideas about flexibility, dexterity, speed, and we were ready to focus on them. But the parent raised the topic, which until then had been completely irrelevant for the administration. For example, cold acclimation training. This is a part of the process and it was also necessary here. Moreover, the room for this group has still no PVC windows. As the parents 
say: "We need air to ensure ventilation". In other groups, no one has asked the parents whether to change the windows... In addition, now this group goes for a walk more than others, in any weather, and this was a direct issue of agreement, because it involved dealing with Sanitary Rules and Regulations. It turned out that in this document there were established ambiguous norms, let us quote: "At a temperature below $-15{ }^{\circ} \mathrm{C}$ and in the case of the wind speed above $7 \mathrm{~m} / \mathrm{s}$ it is recommended to shorten the walk". If for all the others such weather is the reason not to walk at all, here the administrators said like "it is recommended, but it is not obligatory, so we do not need to shorten the time for walk". Further, the phrase " $-15{ }^{\circ} \mathrm{C}$ and gusts of wind with seven $\mathrm{m} / \mathrm{s}$ speed" in this group is interpreted differently from all the other groups. As for these groups if there is only one condition (either $7 \mathrm{~m} / \mathrm{s}$ or $\mathrm{t}$ below $-15^{\circ} \mathrm{C}$ ) children must not go outside, but as for this special group, children do not go outside only when these conditions come together. It turns out that even such stringent norms as Sanitary Rules and Regulations can be discussed in the negotiation process, and the rules' limitations prove to be flexible. Of course, there are some rigid borders, where one can only say like: "No, we cannot move beyond limitations here, unfortunately or fortunately. But in some places we can move and therefore we are ready to negotiate on these points". As regards the planned achievements, the parents literally read the methodological materials that the physical education teacher intended to use (of course, not all 28 people read, but still). As a result the kindergarten administration and the parents agreed on the price of the whole matter, about the work schemes, and the process took off. The agreement has been maintained for the third year already. This year some of these children will go to city competitions to represent their kindergarten.
Another example is from another pole of education process (master's degree students). Most recently, negotiations between lecturers and the first year students of the master's program in conflict management have come to an end. They lasted for two months! The program is designed for two years of study, and two months of them are filled with negotiations about how we will live, how we will arrange their education process. There are only 20 people on the course with nine of them willing to get special attitude, some kind of individualization. What was discussed? We discussed the list of competencies that the students need, and which the teaching staff are ready to give them. This was the first step in coordination. Literally they compiled a list of competencies and levels of their development, and what levels of development can be achieved during their study. What the lecturers are going to do to form these competencies, and what is necessary to reach this goal. These nine people need different things: although not radically different, but there is some diversity. As a result, there is such a matrix of opportunities, in which one can orient on their own and make a really detailed educational program. After that the lecturers and students agreed on how this would happen, they discussed the forms and the timing. Should they be defined for everyone in the same or in different ways? This was also agreed upon. The next question is how we will use the resources of the parties. Who, in what role and when can help anyone, and how will the interaction be arranged? We also got an agreement on the conditions on how to enter and exit the program, how the results should be measured, what achievements suffice to be transferred to another level. It has been a while since the negotiations, and so far everything has been perfect. And if something goes wrong, we know what form to keep this conflict in, and how it can be resolved. 
This couple of examples was brought from the author real conflict "designing" practice and attempts to resolve the conflicts.

It seems to us that the conference "Development Practices" will become a place and a way of formulating and presenting the problems that can be useful. It may become the chance for the community of those aiming at the development of education to have a better picture of this conflict between the individual and mass education:

- Where will the request for education come from? Where and how can the subject (ready for these negotiations, or at least needing these negotiations) be found in reality?

- Opportunities of the institute of negotiations in education: where are they? Where are the borders? This topic is complex, it takes a long time and has no easy answers, because it is difficult to find questions and grounds, where the parties are really interdependent and really manage the resources.

- Individual progress and educational practice. We refer to individual progress; we really want it to become massive. Somehow ensuring everyone's massive and individual progress. How to save the individuality in this progress and who in fact can keep this interest? Who is that subject?

- What professional competencies can maintain this conflict? Due to what and how is such maintenance possible? These are the questions that will worry both those who teach professionals and those who are already professionals and work as practitioners.

- Risks of standardization. It is a very serious question. Where are the borders here? What is interesting here is, for example, preschool education standard, which bears the same conflict. It is called "standard", and its content has such a statement: "do everything to keep them individual, please". And cutting-edge preschool education strives for this. This is a very interesting work. The standard of conditions, as it is called, is a serious work for managers, an exciting task, and in this area a lot of conflicts need to be formed. We are ready to discuss under what conditions we can carry on from not productive excesses and spontaneous clashes to the conflict management.

So, proceeding from the analysis and ideas of constructive psychology, we accept as true that these issues will move us forward to a more productive conflict creation.

At the same time, we hold the belief that attention to individuality and its progress (in terms of increasing the freedom of action and responsibility for results) as a special professional pedagogical trend consists in overcoming one's own pedagogical egocentrism-paternalism. And contrary to the traditional pedagogical purpose (serving massivization) the educators should take the side of individuality, then they have to organize the meeting of the massivization and individualization in a fruitful conflict.

\section{References}

Habermas, J. (1991). Poniatie individual'nosti [The concept of individuality], In O chelovecheskom $v$ cheloveke [On the Human in Man]. Moscow.

Lipovetsky, G. (2001). Era pustoty. Esse o sovremennom individualizme [The era of emptiness. The essay on modern individualism]. Moscow.

Ortega y Gasset, J. (2001). Vosstanie mass [Rebellion of the masses, Russian translation by S.L. Vorob'ev, A.M. Geleskul, B.V. Dubinin et al.]. Moscow. 


\section{Массовое и индивидуальное: \\ организованный конфликт против стихии}

Б.И. Хасан, Т.И. Юстус

Сибирский федеральный университет Россия, 660041, Красноярск, пр. Свободньй, 79

Задача авторов статьи состоит в том, чтобы представить сообществу, как можно видеть конфликт индивидуального и массового образования не только в его разрушительной - деструктивной функиии, но и как полезный, оформляющий и позволяющий продуктивно работать с противоречием массового устройства образовательных институций и установками, притязаниями, намерениями отдельного участника образовательной действительности.

Ключевые слова: индивидуальность, массовое образование, конструктивный конфликт.

Исследование выполнено при финансовой поддержке РГНФ проекта проведения научных исследований «Методические подходы к мониторингу миграционных потоков для формирования системы управления качеством жизни населения регионов Сибири и развития дифференцированной территориальной политики страны», проект № 15-12-24008.

Научная специальность: 19.00.00 - психологические науки. 